\title{
JANA KALWINA ZARYS NAUKI O KOŚCIELE W ŚWIETLE INSTITUTIO RELIGIONIS CHRISTIANAE Z 1543 ROKU
}

\begin{abstract}
„Szczególnie dzisiaj widać wyraźnie, że każdy, bez wyjątku - do jakiego Kościoła czy sekty by nie należał - uchodzić chce za wierzącego, [...] któż jednak był bardziej wierzący i bardziej pewny swojej wiary aniżeli faryzeusze."
\end{abstract}

Sebastian Franck, Paradoxa (1540)'

Europa XVI w. była niewątpliwie areną jednej z największych, a zarazem najistotniejszych przemian wyznaniowych w chrześcijaństwie zachodnim. Choć źródeł tych przemian można doszukiwać się jeszcze w wiekach średnich, jednak to istotne z punktu widzenia historii Kościoła novum ukazało swoją potęgę dopiero w wieku XVI. Poglądy, dążenia i w końcu poczynania niemieckiego mnicha augustiańskiego Marcina Lutra odbiły się szerokim echem w całej niemal Europie. Nie zmienia to oczywiście faktu, iż wcześniej od wittenberskiego zakonnika, działał na polu wyznaniowym chociażby Jan Hus, którego nauka pozostawiła po sobie pewien rozgłos, szczególnie w państwie czeskim. Jednak dopiero tezy głoszone przez Lutra, choć w wielu miejscach zgodne z poglądami czeskiego mistrza Jana, uzyskały właściwy rozgłos i moc przetrwania po dziś dzień. Ruch reformacyjny, za którego ojca wszyscy historycy zgodnie uważają Marcina Lutra, zapoczątkował proces wielkich przemian na polu wyznaniowym i nie tylko.

Niewątpliwie drugim po Lutrze wielkim reformatorem chrześcijaństwa był Francuz Jan Kalwin. Z wykształcenia prawnik, z zamiłowania teolog i myśliciel, starannie wykształcony i nieustannie pogłębiający swą wiedzę z zakresu biblistyki i teologii. Reprezentował on niewątpliwie inną osobowość od Lutra, a także różne od wittenberczyka spostrzeżenia na kwestie Kościoła Powszechnego. Zwykło się także mówić, iż Luter reformował Kościół, a Kalwin zreformował jeszcze Lutra. Różnice bowiem w nauce o Kościele czy sakramentach

\footnotetext{
1 Sebastian Franck - niemiecki ksiądz katolicki, studiował w Ingolstadt i dominikańskim Studium Generale w Heidelbergu. W 1524 r. porzuca katolicyzm. Został kaznodzieją luterańskim, jednak szybko stwierdził, że idee zbyteczności uczynków głoszone przez Lutra, a także sprzeciwiające się wolnej woli, przyczyniają się do stałego pogarszania życia chrześcijańskiego. Poświęcił się wyłącznie pracy pisarskiej, a jego dzieła uważane są przez specjalistów za manifest szesnastowiecznego spirytualizmu chrześcijańskiego. Cyt. za: A. Seguenny, W poszukiwaniu prawdziwej wiary. Szkice z historii religii XVI wieku - humanizm, reformacja, spirytualizm, Lublin 2009, s. 13, 64-66.
} 
uwidaczniają w sposób wyraźny odrębność Kalwina od wcześniejszych założeń niemieckiego mnicha.

Kalwin, podobnie jak Luter, był reformatorem bardzo płodnym. Na swoim koncie ma zarówno nieduże dzieła, jak np. $O$ śnie dusz z 1534 r. czy Traktat o relikwiach powstały w I543 r. Spośród zaś tych największych i zarazem najobszerniejszych, które wyszły spod pióra reformatora, wymienić należy: Komentarze do Pisma Świętego czy Katechizm Genewski z 1545 r. Za największe zaś, a zarazem stanowiące sumę idei religijnych Kalwina, uchodzi bez wątpienia Institutio Christianae Religionis, które w polskim tłumaczeniu brzmi Nauka Religii Chrześcijańskiej. Wydań, które redagował bezpośrednio sam Kalwin, było pięć. Ukazywały się kolejno w latach: I536, I539, I543, I550 oraz I559. Każde wydanie, zredagowane i ukończone przez Kalwina, było każdorazowo drukowane i wydawane, przez co spotkać można w literaturze przedmiotu listę wielu wydań $N a u k i^{2}$. Obszerna księga dotycząca Kościoła została dodana do wydania strasburskiego z I543 r. Choć przeredagowana i nieco uporządkowana w wydaniach późniejszych, niewątpliwie pozostaje punktem wyjścia przy omawianiu eklezjologii francuskiego reformatora. Przed przejściem do omówienia właściwego tematu artykułu z całą stanowczością należy stwierdzić, iż ujęcie tematu w ramy określone jego tytułem jest tylko próbą przybliżenia Czytelnikowi zarysu nauki i poglądów Jana Kalwina na kwestie związane z Kościołem - takim, jakim pragnął go widzieć reformator. Wspomnimy jeszcze, iż dokonując kwerendy literatury przedmiotu, każdorazowo natrafiamy na odwoływanie się autorów ${ }^{3}$ badających ideę Kalwina przede wszystkim do Institutio. Dzieło to stanowi dziś punkt wyjścia dla analizowania i rozważania nauki francuskiego reformatora, której kompendium zawarte jest w kartach Nauki.

Analizując zatem treść naszego dzieła pod kątem nauki o Kościele, nie sposób pominąć milczeniem kwestii związanych także z jednym z sakramentów, mianowicie Wieczerzą Pańską. Sakrament ów bowiem, jego pojmowanie i znaczenie, stał się w pierwszej połowie XVI w. punktem odniesienia w procesie konfesjonalizacji Kościołów wyrosłych na gruncie reformacji. Przedstawiciele powstających w opozycji do Kościoła Rzymskiego wspólnot ewangelickich żywo dyskutowali nad rozumieniem i znaczeniem sakramentu Wieczerzy dla życia chrześcijan-protestantów ${ }^{4}$. W idei, istocie oraz rozumieniu tego sakramentu zawarta jest bowiem szersza nauka. Dotyczy ona istoty Kościoła, darów za jego pomocą przez Stwórcę wiernym rozdawanym, a także miejsca i roli duchownych, rozumianych odtąd nie jako szafarzy ofiary, lecz jako głosicieli Słowa. Poprzez tak rozumiane kwestie eklezjologiczne tłumaczyć należy także fakt zwrócenia szczególnej uwagi na ambonę jako centralne miejsce w kościele, z którego głosi się Słowo Boże, nie zaś ołtarz, na którym składa się ofiarę. W dzisiejszej perspektywie, mając na myśli wspólnotę ołtarza kilku Kościołów ewangelickich, wypada wspomnieć o historycznej dyskusji, której przewodnim tematem była

\footnotetext{
2 Dokładnego spisu wydań Institutio do roku 1600 dokonał A.E. McGrath w swojej pracy: Jan Kalwin. Studium ksztaltowania kultury Zachodu, Warszawa 2009, s. 208-209.

3 Zob. B.C. Milner, Calvin `s Doctrine of the Church, London 1970; L. Boettner, The reformed doctrine of predestination, Grand Rapids, Michigan 1968; P. Helm, John Calvin's Ideas, New York, 2006; B. Gordon, Calvin, Bodmin, Cornwall 2009. Z polskich autorów wymieńmy: A. Tokarczyk, Protestantyzm, Warszawa 1980; S. Piwko, Jan Kalwin. Życie i dzieto, Warszawa 1995; W nurcie myśli Jana Kalwina, w: Ekumenizm i Integracja, red: J. Budniak, P. Jaskóła, R. Porada, t. 22, Opole 2009.

4 Podczas sejmu Rzeszy w Spirze 19 IV 1529 r. większość katolicka przegłosowała ustawę zakazującą szerzenia nauk reformacyjnych. Na skutek tego stany ewangelickie, będące w mniejszości, wystosowały protestację do cesarza Karola V. Od tego momentu zwolenników reformacji w Niemczech zaczęto nazywać protestantami.
} 
kwestia pojmowania sakramentu Wieczerzy. Było to spotkanie reformatorów w Marburgu we wrześniu 1529, które inspirował landgraf Filip Heski. Spotkali się tam Marcin Luter z Ulrykiem Zwinglim, otoczeni swoimi zwolennikamis . Do ugody w kwestii Wieczerzy nie doszło, co jak stwierdza M. Uglorz, było wynikiem głębokich przekonań głównych rozmówców, jak również odmiennych mentalności Lutra i Zwinglego ${ }^{6}$. Nie zmienia to jednak faktu, iż zagadnienia natury teologicznej, a dotyczące zarówno przyszłego funkcjonowania Kościołów, jak również życia religijnego wiernych, były w procesie formowania się konfesji protestanckich jednym z głównych czynników powodujących rozmaite spory i dysputy.

Dodatkowo w części swojego dzieła poświęconej Kościołowi, oprócz kwestii wyżej wymienionych, francuski reformator poruszył także inne wątki związane z szerokim tematem swojej eklezjologii. Dotknął w nich kwestii Mszy, rozumianej przez katolików jako ofiary, kapłaństwa uświęconego sakramentem, a także instytucji Stolicy Apostolskiej, z której rozciąga się na cały Kościół prymat Biskupa Rzymu.

\section{Kościól i jego powszechność}

Na początku naszych rozważań należy zauważyć, iż Kalwin przedstawił i rozróżnił Kościół widzialny od niewidzialnego. Jak zauważył A.E. Mc Grath w swoim studium o Kalwinie i jego wpływie na kulturę zachodniej cywilizacji, zasadnicza różnica między tymi Kościołami polega na tym, iż „w aspekcie niewidzialnym Kościół stanowi zgromadzenie wybranych, znanych jedynie Bogu, w swym aspekcie widzialnym stanowi społeczność wiernych na ziemi. Ta pierwsza składa się wyłącznie $\mathrm{z}$ wybranych, w tej drugiej natomiast znajdują się zarówno dobrzy jak i źli’’. Kalwin określał Kościół mianem matki, która opiekuje się człowiekiem aż do momentu osiągnięcia dojrzałości chrześcijańskiej. Kościół jest człowiekowi niezmiernie potrzebny, gdyż poza nim nie może być on zbawiony. W Kościele człowiek poznaje Boga, czy inaczej Bóg daje się poznawać człowiekowi. Przede wszystkim daję się poznawać poprzez swoje Słowo, a do jego głoszenia i nauczania wyznaczył pastorów, z pomocą których ludzie winni poznawać wiarę ${ }^{8}$. Ciekawie rzecz ujął angielski pastor i teolog prof. Alan Sell. Brzmi ona następująco: „Dla Kalwina Kościół to organizacja skupiająca tych, którzy za pośrednictwem Chrystusa, są świętymi z powołania. Nie jest tak, że najpierw dana jest nam sama Ewangelia, do której doczepiamy Kościół. Przedstawia zjednoczenie z Chrystusem jako Zbawicielem i Panem, które jest równocześnie zjednoczeniem ze wszystkimi, którzy do niego należą. Bóg raczył zdecydować by Jego dzieci wychowywały się na łonie swojej matki - Kościoła tak, aby już od niemowlęctwa otrzymywały odpowiedni pokarm dzięki jej opiece, trosce i mądrości. To Kościół będzie przewodnikiem wiernych dopóki nie dojrzeją i nie wydadzą ostatecznych owoców swojej wiary [...]. Ci bowiem, których ojcem jest Bóg, za matkę mają Kościół"9. Nadto Kalwin wyrażając się na temat Kościoła odnosił się zawsze do jego powszechności,

\footnotetext{
Stronę wittenberską reprezentowali: Marcin Luter oraz Filip Melanchton, zaś szwajcarską Ulryk Zwingli i Jan Oekolampad, zwany Oekolamadiusem. Zob. G.R. Potter, Zwingli, Warszawa 1994, s. 344- 372.

6 M. Uglorz, Marcin Luter-Ojciec Reformacji, Bielsko-Biała 1995, s. 98.

A.E. McGrath, Jan Kalwin - studium ksztaltowania kultury Zachodu, Warszawa 2009, s. 244.

,[...] he has appointed pastors and teachers, by whose lips he might edify his people”, zob. John Calvin, Institutes of the Christian Religion, t. 2, ks. 4, rozdz. 1, Grand Rapids, Michigan 1979, s. 280.

9 A.P.F. Sell, Wyzwania Kalwina wobec Kościoła w XXI wieku, w: „Rocznik Teologiczny Chat”, 51/2009, z. 1-2, s.181-208.
} 
wszechobecności. Jak trafnie ujął ten aspekt B. Cottret według Kalwina „Kościół powszechny jest sumą Kościołów lokalnych"ıo. Ową powszechność rozumiał także Kalwin jako brak granic administracyjnych dla Kościoła. „Jeżeli bowiem dwie różne grupy ludzi mieszkają na przeciwnych stronach świata, lecz wyznają jednego Boga i Chrystusa, przyjęli chrzest i uczestniczą w sakramencie Wieczerzy, to są jednym Kościołem" "II. Uważał nadto, iż wierni powinni szanować Kościół widzialny, mimo iż posiada on swoje słabości. Szacunek ten winien być okazywany ze względu na Kościół niewidzialny jako ciało Chrystusa. Mimo tego rozróżnienia Kościół jest jednak jeden, którego głową jest Chrystus ${ }^{12}$. „Gdziekolwiek widzimy Słowo Boże szczerze głoszone i słyszane, gdziekolwiek widzimy sakramenty administrowane zgodnie z instrukcją Chrystusa, nie możemy mieć wątpliwości, że istnieje tam Kościół Boga"’3.

\section{Biskup Rzymu głową całego Kościoła?}

Francuski reformator próbował dowieść, iż nauka głoszona przez Kościół Rzymski pozostaje w sprzeczności z nauką Chrystusa. W sposób szczególnie krytyczny odnosił się reformator do osoby biskupa Rzymu, teologii katolickiej oraz do praktyk religijnych funkcjonujących w Kościele katolickim. Uważał, iż Kościół Rzymski błądzi sprawując aż siedem sakramentów. Jak wiemy szesnastowieczni reformatorzy chrześcijaństwa uznali ostatecznie dwa: chrzest i Eucharystię (Wieczerzę Pańską), jako te ustanowione przez Chrystusa, mające swoje potwierdzenie w Piśmie Świętym. Nie tylko zresztą te kwestie dotyczące katolickiej nauki podważał Kalwin. Jeśli chodzi o kwestie związane z papiestwem, Kalwin podważał przede wszystkim prymat biskupa Rzymu wobec całego Kościoła. „Przyjrzeliśmy się tym stowarzyszeniom kościelnym, które istniały w ustroju pierwotnego Kościoła, lecz później uległy z czasem demoralizacji [...] i dziś uchowały się w łonie Kościoła papieskiego [...] będąc w istocie niczym innym, niż zwykłą maską"I4. Kalwin nieustająco zadawał pytanie, kto dał papieżowi władzę zwierzchności nad całym Kościołem Powszechnym. Zawarte w Ewangelii przekazanie przez Chrystusa kluczy św. Piotrowi wraz ze słowami: „Ty jesteś Piotr skała, a na tej skale zbuduję mój Kościół”, stały się jednym, jeśli nie jedynym, podmiotem w dyskusji prowadzonej przez obydwie strony sporu. Kalwin twierdził, że św. Piotr był przedstawicielem wszystkich, symbolem całego Kościoła. Nie otrzymał zatem niczego więcej niż inni apostołowie. Dar, który otrzymał św. Piotr, w równej mierze otrzymali oni wszyscy. Odniósł się zresztą w tej kwestii reformator do Augustyna, którego zacytował: „Jeden otrzymał

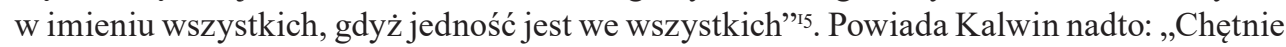
przyznam Piotrowi zaszczytne miejsce pośród pierwszych budowniczych Kościoła [...], nie

\footnotetext{
10 B. Cottret, Jan Kalwin, Warszawa 2000, s. 337.

11, ,...] often too, by the name of Church is designated the whole body mankind scattered throughout the world, who profess to worship one God and Christ, who baptism are initiated into the faith; by partaking of the Lord's Supper profess unity in true doctrine and charity", zob. Institutes..., s. 288.

12 A.E. McGrath, Jan Kalwin..., s. 245.

13, ,...] wherever we see the word of God sincerely preached and heard, wherever we see the sacramento administered according to the institution of Christ, there we cannot have any doubt that the Church of God has some existence", zob. Institutes, s. 289.

$14, \ldots[. .$.$] hitherto we have reviewed those ecclesiastical orders which existed in the government of the primitive$ Church; but afterwards corrupted by time [...] now only retain the name in the Papal Church, and are, in fact, nothing but mere masks", zob. Institutes..., s. 353.

15, ,...] one received for all, because there is unity in all” (Hom. 124), zob. Institutes, s. 356.
} 
pozwolę im jednak wydedukować z tego, iż ma on pierwszeństwo nad innymi’’6. Tłumaczył dalej Kalwin, iż nie odbiera św. Piotrowi jego zalet oraz wielkiej gorliwości w głoszeniu chrześcijańskiej doktryny. Jego mądrość niewątpliwie dawała mu władzę nad innymi. Jednak zaznaczył, że przecież przed Piotrem był Andrzej, który faktycznie ukazał mu Chrystusa. Kalwin zdecydowanie rozgraniczał godność rangi z posiadaniem władzy. Twierdził dalej, że Pismo Święte jednoznacznie ukazuje św. Piotra jako jednego z dwunastu równych sobie uczniów Chrystusa, nie zaś jako ich pana. Wskazuje również na czynności wykonywane przez Piotra, które w niczym nie przypominały tych, które wykonywałby władca jakiejś grupy. Przytacza, że gdy Piotr pisał do duszpasterzy, to nie rozkazywał im apodyktycznie jak zwierzchnik, tylko uprzejmie im doradzał. Gdy zaś oskarżono go o chodzenie do pogan, bronił się i zwyczajnie oczyszczał z zarzutów. Apostołowie powierzając Piotrowi różne misje nie uważali go zapewne za swojego zwierzchnika. On także, wykonując ich polecenia, niejako potwierdzał, iż nie miał nad nimi żadnej władzy. Św. Piotr został wybrany przywódcą apostołów, to oni powierzyli mu owe przywództwo - taki tok rozumowania przybrał w tej kwestii Kalwin. Stwierdził ponadto dalej, kontynuując wątek papieski: „Lecz organizacja, która sprawdziła się w przypadku kilku osób, nie da się po prostu przełożyć na cały świat, którym nie może rządzić tylko jeden jedyny człowiek" ${ }^{17}$. Tym przykładem porównywał reformator władzę papieską nad całym Kościołem powszechnym. Przez szereg kart swojego dzieła Kalwin dywagował nad kwestiami władzy papieża, Rzymu jako stolicy i ośrodka władzy w Kościele, czy sukcesji papieskiej począwszy od św. Piotra. Z tych przemyśleń wyłania się teza, którą zdaje się reformator chciał przekazać i jej bronił. Mianowicie, że papież nie jest głową widzialnego Kościoła powszechnego, nikt bowiem nie dał mu takiej władzy. Rzym również nie może być uważany za stolicę chrześcijaństwa, bo jeżeli mieć na względzie czas pobytu św. Piotra w wiecznym mieście, to należy zwrócić uwagę na fakt, że np. w Antiochii przebywał on dłużej. Biskup, pastor, diakon - wszyscy duchowni w Kościele są równi wobec siebie, a ewentualne pierwszeństwo jest tylko i wyłącznie reprezentacyjne.

\section{Kwestia Mszy}

Lecz nie tylko w kwestiach, zdawałoby się podstawowych, ogólnych, Kalwin dopuszczał się krytyki Kościoła katolickiego. Jego negacja nauki i teologii dotykała w sposób bardzo konkretny poszczególnych elementów katolicyzmu. Kolejną z kwestii dotyczących krytyki nauki katolickiej była ta dotycząca Eucharystii rozumianej jako ofiary Chrystusa składanej każdorazowo na ołtarzu. Przede wszystkim Kalwin odrzucił katolicką naukę o Mszy św. jako ofiarze na odpuszczenie grzechów. Msza, jak twierdził, „nie jest dziełem, przez które kapłan, który ofiarowuje Chrystusa i inni, którzy Go w ofierze otrzymują, mają zasługę u Boga lub, że jest to ofiara pokutna"'18. Kalwin odrzucił także zdecydowanie możliwość, że Msza mogłaby być przebłaganiem za żywych i umarłych. Reformator zauważył, że choć Msza może zewnętrznie okazale wyglądać poprzez rozbudowana liturgię, być lśniąca i wspaniała, to mimo tego jest

\footnotetext{
$16,[\ldots]$ I willingly concede to Peter the honour of being placed among the first in the building of the Church [...] but I will not allow them to inter from this that he has a primacy over others", zob. Institutes..., s. 357.

17 ,...but an arragment which is effectual among a few must not be forthwith transfer red to the whole world, which no one man is able to govern.."., zob. Institutes, s. 358.

$18, \ldots[. .$.$] that the mass is a work by which the priest who offers Christ, and the others who the oblation receive him,$ gain merit with God, or that it is an expiatory victim", zob. Institutes, ks. 4, rozdz. 18, s. 607.
} 
w istocie obrazą Boga. Mówiąc o Mszy Kalwin powiązał z nią także rolę kapłana przy sprawowaniu Ofiary, jak również kwestie zastępstwa Chrystusa na ziemi przez duchownych. Jak dowodził dalej reformator, Chrystus został wybrany przez Boga kapłanem i arcykapłanem na wieczne czasy. Udowadniał, że w czasach Starego Testamentu kapłanów wybierano na określony czas, ponieważ ich życie było śmiertelne. Każdy nowy zastępował więc poprzedniego. Chrystus natomiast, ponieważ jest nieśmiertelny, nie potrzebuje żadnego kapłana, który mógłby Go zastąpić. Jeżeli zatem ofiarę eucharystyczną sprawują kapłani jako wikariusze, a zarazem następcy Chrystusa, to okradają Go tym samym z Jego czci i przywileju wiecznego kapłaństwa. Zwróćmy w tym miejscu uwagę na fakt, że Kalwin nie neguje istoty kapłaństwa samego w sobie, lecz domaga się tylko, aby było ono postrzegane i rozumiane jako forma zastępstwa Chrystusa w Jego wiecznym, nieśmiertelnym kapłaństwie, które nigdy nie przestaje istnieć. Wspomniał jeszcze reformator, opierając się na Biblii, że „prawość i godność kapłaństwa skończyła się pośród ludzi śmiertelnych, ponieważ Chrystus, który jest nieśmiertelny, jest jedynym wiecznym kapłanem"ঙ9. Ołtarz, na którym sprawuje się ofiarę Chrystusa, niweczy i neguje, zdaniem Kalwina, tę złożoną niegdyś na krzyżu. Jak wykazuje francuski reformator, moc i skuteczność ofiary krzyżowej Chrystusa jest aktualna i kontynuowana bez końca, zatem działa wiecznie. Jeżeli wobec tego każda Msza jest powtórzeniem tej ofiary, to znaczyłoby że śmierć Chrystusa na krzyżu była niewystarczająca, skoro wymaga ciągłych powtórzeń. „Gdyby tak było, to nie moglibyśmy myśleć o Chrystusie czcigodniej niż o wołach czy cielętach, które niegdyś składane były w ofierze, a okazywały się nieskuteczne, gdyż często je powtarzano"º. Całą naukę w tej materii głoszoną przez Kościół katolicki Kalwin bardzo dokładnie analizował, co należy reformatorowi przyznać. Komentując lub co częstsze, krytykując daną gałąź nauki Kościoła rzymskiego, czynił to nie pochopnie, lecz po dokładnym przeanalizowaniu danej kwestii. Przykładem tego niech będzie ukazanie przez Kalwina ustępu z proroctwa Malachiasza, na podstawie którego, zdaniem reformatora, bazuje nauka katolicka dotycząca znaczenia i rozumienia Mszy św. Fragment cytowany w dziele brzmi następująco: „Albowiem od wschodu słońca aż do zachodu wielkie będzie imię moje między narodami, a na każdym miejscu dar kadzielny będzie składany imieniu memu i ofiara czysta. Albowiem wielkie będzie imię moje między narodami - mówi Pan Zastepów”2r. Kalwin słowa proroka tłumaczył jako duchową zachętę do oddawania czci Bogu. Na dowód duchowości znaczenia tych słów, przytacza słowa z proroka Izajasza, który mówił o trzech ołtarzach, które miały być wzniesione w Asyrii, Egipcie i Judei. Wskazuje, iż nigdy takowe nie powstały, co jest według niego potwierdzeniem duchowości prorockich przepowiedni odnoszących się do czczenia chwały Bożej.

W swoich rozważaniach na temat Mszy Kalwin stwierdził, iż jest ona również nowym i całkowicie innym testamentem niż ten, który pozostawił po sobie Chrystus Pan. On bowiem obiecał w swym testamencie odpuszczenie grzechów wszystkim ludziom. Testament swój potwierdził swoją śmiercią, inaczej mówiąc, przypieczętował zawarte w nim obietnice, że Jego śmierć gładzi ludzkie grzechy. Kalwin zatem stwierdził, że wprowadzanie do testamentu Chrystusa wszelkich zmian jest zaprzeczeniem Jego śmierci, która testament

\footnotetext{
$19,[\ldots]$ that the right and honour of the priesthood has ceased among mortal men, because Christ, who is immortal, is the one perpetual priest", zob. Institutes, s. 608.

${ }^{20},[\ldots]$ otherwise, we should not think more honourably of Christ than of the oxen and calves which were sacrificed under the law, the offering of which is proved to have been weak and inefficacious because of ten repeated", zob. Institutes, s. 609.

${ }^{21}, \ldots[. .$.$] in every place incense shall be offered unto my name, and a pure offering”, zob. Institutes, s. 610$.
} 
ów potwierdza. Reformator postawił następujące pytanie: „Czy każda Msza nie obiecuje nowego przebaczenia grzechów, nowego dostąpienia sprawiedliwości, tak, że teraz jest tyle testamentów ile Mszy?"22 Tym dowodem, przykładem, Kalwin pragnął potwierdzić swoja tezę postawioną na początku swoich rozważań na temat Mszy, mianowicie: „czyż nie powiedziałem prawdy, wtedy, na początku, że jedyna prawdziwa śmierć Chrystusa jest zatarta przez Mszę?"’23 Powołując się na list do Hebrajczyków św. Pawła reformator podaje, że musi ponieść śmierć ten, kto sporządza testament. To błędne pojmowanie Mszy polega według Kalwina na tym, iż jest ona rozumiana jako testament Chrystusa, a co za tym idzie wymaga także Jego śmierci. Ponieważ każda ofiara winna być uśmiercona i poświęcona, zatem Chrystus będąc poświęcany podczas każdej Mszy również wymaga uśmiercenia w jednej chwili w tysiącach miejsc ${ }^{24}$. Zauważa także reformator, że katolicy mówią o bezkrwawej ofierze, co on natychmiast ripostuje mówiąc iż ,nie należy to do woli człowieka zmieniać naturę ofiary, bo w ten sposób święta i nietykalna instytucja Boga upadłaby”25. Dodał przy tym zrazu cytat ze św. Pawła, który pisząc do Hebrajczyków mówił o konieczności rozlania krwi, gdy ma się dokonać odpuszczenie grzechów ${ }^{26}$. Czy można myśleć o odkupieniu przez Chrystusa i być go pewnym, widząc jednocześnie nowe odkupienie we Mszy, pytał Kalwin? Jak można być pewnym odpuszczenia grzechów, gdy widzi się za każdym razem kolejne odpuszczenia podczas Mszy? Reformator dostrzegał w tej katolickiej nauce w zasadzie same błędy, których jak twierdził, Kościół rzymski broni „krzykiem, ogniem i mieczem”27.

\section{Wieczerza Pańska. Ofiara czy pamiątka?}

Dość obszernie w swoim Institutio, w księdze poświęconej Kościołowi, Kalwin poruszył także kwestię sakramentu Wieczerzy Pańskiej, który jest nieodzownym elementem zarówno Mszy św., jak i stoi on w centrum sakramentologii ewangelickiej. Ujęciem rzeczonego sakramentu, jego teologicznym wymiarem, jaki proponował Kalwin, nie będziemy się tutaj zajmować. Zasadnym wydaję się jednak na potrzeby niniejszego artykułu przyjrzeć się samej kwestii sprawowania sakramentu Wieczerzy w Kościele w sposób, jaki proponował genewski reformator. Otóż twierdził on, że święta Wieczerza została z Kościoła całkowicie usunięta oraz zniszczona z chwilą, gdy ustanowiono Mszę św. Dzieję się tak, ponieważ Wieczerza jest darem otrzymanym od Boga, który ludzie powinni przyjąć z wielką wdzięcznością. Msza natomiast, poprzez naturę ofiary, przypomina według Kalwina bardziej danie Bogu zadośćuczynienia. Stwierdził on: „tak bardzo jak dawanie różni się od przyjmowania, tak ofiara różni się od sakramentu Wieczerzy”28. Bóg, twierdzi dalej, nie nakazał wiernym skła-

\footnotetext{
$22,[\ldots]$ now, that is the mass but a new and altogether different testament? What? Does not each mass promise a new forgiveness of sins, a new purchase of righteousness, so that now there are as many testaments as there masses?", zob. Institutes, s. 610.

23, ,[...] said I not true, then, at out set, that the only true death of Christ is obliterated by the mass?", zob. Institutes, s. 611.

24 Institutes, s. 611.

25 „I will reply, that it depends not on the will of man to change the nature of sacrifice, for in this way the sacred and inviolable institution of God would fall", zob. Institutes, s. 611.

26 Ibidem.

$27, \ldots[.$.$] they defend by clamour, fire and sword”, zob. Institutes, s. 612$.

$28,[\ldots]$ as widely as giving differs from receiving, does sacrifice differ from the sacrament of the Supper", zob. Institutes, s. 612.
} 
dać ofiary, tylko słuchać Jego Słowa. Jak zatem doktorzy od mszału, mogą wierzyć w moc i znaczenie składanej przez siebie ofiary? Według Kalwina ofiara oraz jej składanie miały sens w czasach Starego Testamentu, kiedy były one praktykowane. Kapłani, którzy je składali, czynili to na wzór tej, którą miał dopełnić Chrystus. Ofiarę taka składano, budowano dla niej ołtarz, a czyniono tak, aby sprawić większe wyobrażenie o ofierze jako składanej na zadośćuczynienie Bogu. Wszystko jednak zmieniło swoje znaczenie i sens z chwilą, gdy dokonała się ofiara Chrystusa. Bóg dał od tej chwili wiernym stół do ucztowania, nie zaś ołtarz do składania ofiary. Idąc dalej, reformator twierdził, że Bóg nie udzielił konsekracji kapłanom, aby ci składali ofiary, lecz powołał pastorów, aby rozdzielali ucztę wśród wiernych. Ofiarę rozumiał zatem Kalwin jako wyraz wdzięczności lub błagania, które człowiek wyraża Stwórcy. Rozróżniał wyraźnie przy tym ofiary błagalne i dziękczynne. Pierwsze składane były jako oblacje za grzechy, które miały także odkupić winę w oczach Boga. Ofiary dziękczynne natomiast były wyrazem wdzięczności składanej Bogu za otrzymane łaski. Ofiary, szczególnie błagalne, nie były zdaniem reformatora wystarczające, aby zmazać winę człowieka przed Stwórcą. Jedyną wystarczającą ofiarą przebłagalną i zadość czyniącą była bowiem ta złożona przez Chrystusa na krzyżu. Raz po wszystkie czasy. Msza jako ofiara, która ma na celu zdobycie odpuszczenia grzechów, przebłagania Boga i otrzymanie usprawiedliwienia, była dla Kalwina obrazą i świętokradztwem. Zwieńczeniem, a może kwintesencją, tego krótkiego zarysu nauki francuskiego reformatora o Wieczerzy Pańskiej niech będą słowa: „Sam Chrystus, który przypieczętowuje naszą pewność usprawiedliwienia podczas Wieczerzy, nie nakazuje swoim uczniom nagle przerywać tego aktu, ale odsyła ich do ofiary swojej śmierci, dając do zrozumienia, że Wieczerza jest przypomnieniem lub jak się powszechnie wyraża pamiątką, dzięki której mogą się dowiedzieć, że ofiara ekspiacyjna na przebłaganie Boga miała być złożona tylko raz”29.

Pisząc o Kościele Kalwin nie omieszkał również odnieść się do kapłaństwa katolickiego, którego przedstawicielom zarzucał zbyt ochocze dążenie do sprawowania urzędów. Twierdził dalej, iż w Piśmie Świętym nie została postawiona teza, która by jednoznacznie potwierdzała szczególne, powołaniowe znaczenie kapłaństwa. Zauważyć można, iż nie tylko Biblia stała się w tym przypadku podstawowym źródłem dla rozważań reformatora w tej kwestii. Znajdujemy także dość częste odwoływanie się do Ojców Kościoła, a także do historii chrześcijaństwa pierwszych wieków. Według reformatora jedynym i wiecznym kapłanem jest Jezus Chrystus, w którym są wszystkie urzędy kapłańskie.

Jan Kalwin, choć z wykształcenia był prawnikiem, dał się niewątpliwie poznać potomnym jako człowiek głęboko zatroskany o sprawy Kościoła i religii. Choć w swoich poglądach często bardziej radykalny od Marcina Lutra, jednak stworzył podwaliny pod budowę i organizację nowego, różnego od luterańskiego, wyznania chrześcijańskiego. Dał początek, teologicznie, organizacyjnie i intelektualnie dla powstania ewangelicyzmu reformowanego. Jego bezkompromisowość w kwestiach wiary, której dał wyraz niejeden raz w czasie swojego życia, uczyniły z niego niewątpliwie drugiego wielkiego reformatora chrześcijaństwa zachodniego, obok ojca reformacji Marcina Lutra. Skrystalizowane poglądy, o których wybranej części traktował niniejszy artykuł, dają obraz człowieka zdeterminowanego oraz

29 "Christ himself, when he seals our assurance of pardon in the Supper, does not bid his disciples stop short at that act, but sends them to the sacrifice of his death; intimating, that the Supper is the memento, or, as it is commonly expressed, the memorial from which they may learn that the expiatory victim by which God was to be appeased was to be offered only once", zob. Institutes, s. 611. 
nastawionego na wcielanie ich w życie. Pewnie dlatego jest on postacią, do której coraz częściej sięgają historycy oraz przedstawiciele innych dyscyplin.

\section{The outline of John Calvin's teaching on the Church in the light of Institutio Religionis Christianae from 1543 Summary}

One of the main postulates of the reformation movement, apart from the theological questions, was a proposal of the internal reform of the church institution. The Father of the Reformation, as Rev. Martin Luther is called in the source literature, raised the questions concerning the mission of the Church, its role in the magisterium, and also and perhaps above all its hierarchical structure and about the role of the clergy in the process of the eternal salvation. As a result of his reflections and probably his observations and his own experiences Luther undermined in succession different dogmatic, theological questions as well as those regarding the organization of the Roman Catholic Church. Slogans of renewal and reforms of the church structure spread very rapidly through the territory of German Reich, gaining numerous supporters among European nations. One of those for whom the Reformation ideas became the main field of activity was French man John Calvin. That well-rounded, well educated and well-read lawyer, knowing the main works of the German monk, acquired his principal theses postulating the changes in the functioning of the Church. Additionally, Calvin made a division of the Church between the earthly - the visible and the heavenly - the invisible one, and the person who bonds it, guarantees its unity and permanency, the indivisibility is the only and the highest Priest - Jesus Christ. In the work of his life Institucio Religionis Christianae Calvin embodied a full picture of the Christian Church as, in his opinion, it should be. Analysing particular issues regarding the function of the clergymen, the pope, celebrating the sacraments, penance and conversion, and also the eternal salvation, we are given the basic compendium of knowledge concerning the ecclesiology by John Calvin. His teaching about the Church, although in some points different in from the preaching of Rev. Martin Luther, however oscillates within the principal slogans of Reformation: Sola Fides the man is saved solely by faith, Sola Gratia - God's grace is necessary for salvation, Sola Scriptura - the only source of faith is the Holy Bible. He also added the idea: Solus Christus - only Christ saves, He is in the centre of The Church, we can observe Calvin's Christ centred attitude in his preaching and in building ideological basics of the reformed denomination.

Keywords: John Calvin, The Reformed Church in $\mathrm{I}^{\text {th }}$ century, Institucio Religionis Christianae, Protestantism in $\mathrm{I}^{\text {th }}$ century

Nota o Autorze: Grzegorz Wodziński, Doktor nauk humanistycznych w zakresie historii. Pracownik Biblioteki Wydziału Nauk Historycznych i Społecznych UKSW w Warszawie. Prowadzi także zajęcia w Instytucie Nauk Historycznych UKSW. Zajmuje się historią reformacji protestanckiej w Europie i w Polsce, ze szczególnym uwzględnieniem historii ewangelicyzmu reformowanego. Autor artykułów naukowych z zakresu historii idei reformacyjnych, życia religijnego protestantów polskich, historii wspólnot protestanckich. Szczególne zainteresowania: organizacja Kościołów reformacyjnych, liturgia protestancka, historia idei religijnych XVI - XVII w. 